\title{
HUBUNGAN PENGETAHUAN DAN SIKAP TERHADAP PEMBERIAN TERAPI INSULIN DALAM SITUASI NON-CRITICAL PASIEN DIABETES MELITUS
}

\author{
Abd Gani Baeda \\ Program studi Keperawatan Universitas sembilanbelas November, Kampus FIK-UI \\ e-mail: abganbaeda@gmail.com
}

\begin{abstract}
ABSTRAK
Diabetes melitus merupakan penyakit gangguan metabolik akibat kurangnya produksi dan penggunaan insulin oleh tubuh, sehingga menyebabkan hiperglikemia kronik. Salah satu terapi yang sudah terbukti untuk mengontrol gula darah adalah Insulin. Tujuan penelitian ini untuk mengetahui hubungan pengetahuan dan sikap terhadap perilaku perawat dalam memberikan insulin pada pasien diabetes melitus. Metode penelitian menggunakan rancangan Crosssectional yang melibatkan 103 perawat di ruang bedah dan interna. Hasil penelitian diperoleh tidak ada hubungan yang signifikan baik pengetahuan dan sikap terhadap sikap perawat dalam memberikan terapi insulin non critikal. Secara umum sekitar $67 \%$, responden memiliki pengetahuan cukup, $50 \%$ responden memiliki sikap positif, $61,2 \%$ responden berperilaku baik dalam pemberian terapi insulin.Dibutuhkan pelatihan pengelolaan insulin dan manajemen DM secara berkala untuk meningkatkan pengetahuan dan perilaku yang memuaskan.
\end{abstract}

Kata kunci :Diabetes melitus, non critical, pengetahuan, sikap, perilaku, terapi insulin, perawat.

\section{ABSTRACT}

Diabetes mellitus is a chronic metabolic disorder disease caused by ineffective production of insulin used by the body causing hyperglycemia. Blood sugar is controlled by insulin. One of the therapy in control blood sugar is insulin. The aim of this study was to find out the corelation among nurses knowledge, attitudes and behaviors in handling and administering insulin. $A$ Cross-sectional design study involving 103 nurses in the surgery and internal room applied to this study. The results showed that, there was no significant corelation between knowledge and attitudes toward nurses' behavior in providing noncritical insulin therapy. A majority of respondents have $67 \%$ moderat knowladge , $50 \%$ of respondents have positif attitude, and $61.2 \%$ of respondents have satisfactory behaviour. The Conclusion of this study was the training is required to improve knowledge and satisfactory performance.

Keywords: Diabetes mellitus, noncritical, knowledge, attitude, behavior, insulin therapy, nurses. 


\section{PENDAHULUAN}

Diabetes melitus (DM) adalah penyakit gangguan metabolik yang terjadi akibat kurangnya produksi dan penggunaan insulin oleh tubuh, sehingga menyebabkan hiperglikemia kronik [1]. Diabetes melitus ditandai dengan adanya gangguan sistem metabolisme karbohidrat, protein dan lemak akibat kinerja insulin yang menurun [2].

Badan kesehatan dunia World Health Organization (WHO) mengatakan sekitar 180 juta jiwa di dunia hidup dengan DM' International Diabetes Federation (IDF) merilis data di tahun 2013 jumlah penderita DM tipe 2 sebesar 382 juta jiwa dan memperkirakan akan terjadi peningkatan $55 \%$ menjadi 592 juta orang di tahun 2035 [3]. Tahun 2007- 2013 penderita DM di tanah air sebanyak $5.7 \%$ menjadi $6.9 \%$ pada tahun 2013, artinya terjadi peningkatan $2.1 \%$ atau mencapai 9.1 juta jiwa di tahun 2013 [4]. Berdasarkan data tersebut memperlihatkan bahwa, prevalensi diabetes setiap tahunya terus meningkat, sehingga menjadi masalah kesehatan yang serius [5].

Diperkirakan peningkatan jumlah pemakai insulin semakin bertambah seiring sifat diabetes yang progresif serta hiperglikemia tidak terkontrol [6]. Hiperglikemia tidak terkontrol dapat menyebabkan komplikasi [7].

Berbagai komplikasi akibat diabetes tidak terkontrol diantaranya: gagal ginjal (nefropati), kebutaan, neuropati, penyakit jantung bahkan menyebabkan amputasi [8]. Komplikasi yang terjadi tersebut akibat insulin yang mengalami resisten dan diikuti disfungsi sel beta pada pancreas [9]. Oleh karena itu pengontrolan KGD melalui terapi insulin sangat penting dan berkontribusi dalam mengatasi DM serta komplikasi [10].

Insulin adalah salah satu pilihan terapi yang digunakan untuk mengontrol GD di RS (rumah sakit) karena sudah terbukti memiliki kelebihan paling baik, mampu memperbaiki, dan menurunkan GD secara efektif [11]. Namun penanganan terapi insulin yang tidak tepat dapat membahayakan pasien [12]. Insulin juga merupakan sepuluh obat resiko tinggi dengan tingkat kesalahan penggunaan tidak tepat, yang menyebabkan cedera dan kerugian besar, serta kejadian hipoglikemia pada pasien DM yang menjalani terapi [13].

\section{METODOLOGI}

Penelitian ini menggunakan rancangan "cross sectional study", dengan penetapan jumlah sampel menggunakan metode purposive sampling. Sampel dalam penelitian ini adalah semua perawat yang bertugas di RSUD BLUD Benyamin Guluh Kabupaten Kolaka di ruang perawatan interna dan bedah dewasa. Dalam melakukan penelitian, peneliti patut memegang asasasas penelitian. Dalam melakukan penelitian, peneliti perlu mempertimbangkan etika sosial dan harkat manusia. Beberapa prinsip etik dalam sebuah penelitian yakni beneficience, respect of human dignity, dan justice [14]

Pengumpulan data dalam penelitian ini, peneliti menggunakan empat kuesioner, yakni kuesioner A, B, C, dan D. Kuesioner "A"( karakteristik responden) seperti; umur, jenis kelemin, pendidikan, pelatihan, lama kerja. Kuesioner "B"(pengetahuan), kuesioner "C"(sikap), kuesioner "D" (perilaku).

\section{HASIL DAN PEMBAHASAN}

Berdasarkan hasil analisis univariat menunjukkan bahwa rat-rata usia responden adalah diantara 28,66 sampai dengan 30,72 tahun. Usia paling muda 22 tahun dan tertua 55 tahun. Dalam penelitian ini responden yang berjenis kelamin perempuan sebanyak 84 orang $(81,6 \%)$ dan responden laki-laki berjumlah 19 orang $(18,4 \%)$. Diketahui tingkat pendidikan terbanyak ialah vokasi yang berjumlah 80 orang $(77,7 \%)$, selanjutnya 
berpendidikan profesi berjumlah 23 orang (22,3\%). Hasil analisis juga memperlihatkan bahwa responden yang belum pernah mengikuti pelatihan atau kegiatan (seminar) yang berkaitan dengan manajemen diabetes dan terapi insulin sebanyak 83 orang $(80,6 \%)$ dan yang sudah pernah mengikuti pelatihan sebesar 20 orang (19,4\%).

Data selanjutnya memperlihatkan bahwa perawat dari hasil analisis juga memperlihatkan pengetahuan responden terdiri dari pengetahuan kurang, cukup, dan baik. Perawat yang berpengetahuan kurang sebanyak 27 orang (26,2\%), berpengetahuan cukup sebanyak 69 orang (76,0\%), dan yang berpengetahuan baik terdiri dari 7 orang $(6,8 \%)$. Sedangkan sikap responden dibagi dua kategori yakni positif dan negatif. Pada variabel sikap, diperoleh sikap positif sebanyak 51 orang $(49,5 \%)$ dan responden yang menunjukkan sikap negatif sebanyak 52 orang $(50,0)$. Sementara perilaku responden terdiri dari yang berperilaku tidak memuaskan dan memuaskan. Sebanyak 40 orang (38\%) yang berperilaku tidak memuaskan dan sebanyak 63 orang $(61,2 \%)$ yang berperilaku memuaskan.

Dari analisis bivariat dengan uji ChiSquare diperoleh tidak ada perbedaan bermakna pada pengetahuan, sikap, usia, jenis kelamin, dan pendidikan terhadap perilaku pemberian terapi insulin dalam situasi non critical pada pasien DM di RSUD BLUD Benyamin Guluh.

Tabel 1 Hasil Analisis Bivariat

\begin{tabular}{|c|c|c|c|}
\hline \multirow{3}{*}{ Variabel } & \multicolumn{2}{|c|}{ Perilaku Pemberian Terapi Insulin } & \multirow{3}{*}{$P=$ Value } \\
\hline & Tidak Memuaskan & Memuaskan & \\
\hline & $\mathbf{N}$ & $\mathbf{n}$ & \\
\hline
\end{tabular}

\section{Pengetahuan}

$\begin{array}{lccccc}\text { Kurang } & 11 & 40,7 & 16 & 59,3 & \\ \text { Cukup } & 28 & 40,5 & 41 & 59,5 & 0,386 \\ \text { Baik } & 1 & 14,3 & 6 & 85,7\end{array}$

\section{Sikap}

$\begin{array}{rrrrrr}\text { Negatif } & 23 & 45,1 & 28 & 54,9 & 0,276 \\ \text { Positif } & 17 & 32,7 & 35 & 67,3 & \\ \text { Usia } & 40 & 38,8 & 63 & 61,2\end{array}$

\section{Jenis Kelamin}

$\begin{array}{cccccc}\text { Laki-laki } & 6 & 31,6 & 13 & 68,4 & 0,647 \\ \text { Perempuan } & 34 & 40,5 & 50 & 59,5 & 0,518\end{array}$

\section{Pendidikan}

\begin{tabular}{cccccc} 
Vokasi & 30 & 37,5 & 50 & 62,5 & 0,783 \\
Profesi & 11 & 43,5 & 13 & 56,5 & \\
\hline Bermakna pada $\alpha=0,05$ & & &
\end{tabular}


Perilaku perawat dalam pemberian terapi insulin ialah perilaku perawat dalam memberikan insulin di unit pelayanan RS yang menunjukkan performa aktifitas atau tindakan yang sesuai standard dan ketentuan yang disepakati agar meminimalkan resiko serta mencegah kerugian besar pada pasien DM yang menerima terapi insulin akibat hipoglikemia[12].

\section{Hubungan Usia Dengan Perilaku Perawat Dalam Pemberian Terapi Insulin Non Critical}

Hasil uji Mann Whitney menunjukkan bahwa tidak ada perbedaan bermakna antara usia dengan perilaku pemberian terapi insulin dengan $(p=0,518, \alpha 0,05)$. Artinya tidak ada hubungan yang signifikan antara usia dengan perilaku perawat dalam pemberian terapi insulin dalam situasi non critical pada pasien DM di BLUD RS Benyamin Guluh. Hasil penelitian ini tidak sama dengan penelitian yang dilakukan oleh Refrensi [15], [16] yang menyatakan bahwa penambahan usia seseorang diharapkan dapat mempengaruhi kinerja dan produktifitas dalam pelayanan keperawatan menjadi lebih baik dan mempengaruhi kualitas dalam bekerja, mengingat kelompok usia responden tergolong masa produktif dengan lama kerja lebih 5-10 tahun lebih banyak.

Pada penelitian ini usia tidak lagi menjadi pengaruh meskipun usia dapat mempengaruhi kematangan berpikir seseorang. Kondisi RS yang belum menjalankan sistem Continous Professional Development (CPD) dengan baik sangat berpengaruh, sebab meskipun perawat ratarata usia produktif, jika tidak didukung dengan pengembangan karir berupa pendidikan atau pelatihan mengenai manajemen DM dan farmakologi dari RS, maka perawat tidak dapat menunjang performa yang baik dalam pelayanan keperawatan. Sehingga baik usia dewasa awal dan akhir memiliki kesempatan yang sama untuk berperilaku yang memuskan dalam memberikan pelayanan keperawatan tergantung pengalaman dalam mengelola pasien DM yang menjalani terapi insulin dan sumber daya manusia.

\section{Hubungan Jenis kelamin dengan perilaku perawat dalam pemberian terapi insulin non critical.}

Hasil penelitian dengan uji ChiSquare $(p=0,647)$ yang berarti tidak ada hubungan signifikan antara jenis kelamin dengan perilaku perawat dalam pemberian terapi insulin non critical pada pasien DM di BLUD RS Benyamin Guluh. Studi ini menunjukkan bahwa perilaku memuaskan oleh responden dengan jenis kelamin perempuan sebanyak 50 orang $(59,5 \%)$ dan perilaku tidak memuaskan oleh laki-laki 6 orang (68,4\%). Analisis data ini menggambarkan bahwa responden perilaku yang memuaskan lebih banyak dilakukan oleh laki-laki, ketimbang persentase wanita. Persentase jawaban ini menunjukkan adanya kecenderungan bahwa jenis kelamin memiliki 
pengaruh terhadap perilaku. Penelitian ini menunjukkan bahwa meskipun jumlah perawat laki-laki sedikit namun secara persentase menunjukkan perilaku memuaskan dari pada perempuan.

Hasil penelitian yang sama dilakukan, melalui publikasi Refrensi mengungkapkan bahwa kurangnya paparan pasien DM yang menjalani terapi insulin sehingga mempengaruhi pengetahuan dan performa baik perawat pria maupun perawat wanita dalam mengelola pasien DM. Studi ini mengungkapkan bahwa jenis kelamin tidak memiliki hubungan terhadap pengelolaan dalam pemberian dosis dan penyuntikan insulin pada pasien DM.

Pada penelitian ini peran jenis kelamin tidak dapat dijadikan kesimpulan dan dijadikan isu terhadap pengaruh dalam pelayanan, namun dapat dilihat secara luas seperti bagaimana pengetahuan dan pengalaman perawat dalam mengelola pasien DM dengan terapi insulin lebih penting dari perbedaan jenis kelamin. Selain itu perbedaan distribusi jumlah responden pria dan wanita dalam penelitian yang tidak sebanding juga diyakini mempengaruhi nilai akhir statistik. Hasil penelitian ini didukung oleh penelitian Refrensi [18] yang menyatakan bahwa dari sampel penelitian yang dilakukan tidak dapat memastikan bagaimana perilaku memiliki hubungan yang tidak signifikan terhadap jenis kelamin, namun kondisi tersebut diyakini karena adanya sebaran data responden laki-laki dan perempuan yang tidak sebanding. Meskipun demikian perawat merupakan profesi yang memiliki tanggung jawab dan bekerja secara profesional untuk mewujudkan pelayanan yang baik dengan mengabaikan isu-isu yang dapat mengganggu pelayanan seperti isu gender dan budaya.

\section{Hubungan Pendidikan dengan perilaku} perawat dalam pemberian terapi insulin non critical

Hasil uji Chi-Square diperoleh nilai $(p=$ 0,873) dapat disimpulkan bahwa tidak ada hubungan yang signifikan antara pendidikan vokasi dan profesi dengan perilaku perawat dalam pemberian terapi insulin dalam situasi non critical pada pasien DM di BLUD RS Benyamin Guluh. Hasil penelitian ini berseberangan dengan pendapat Refrensi [19] yang mengutarakan bahwa pendidikan tinggi dapat mempengaruhi kemampuan serta kepatuhan individu dalam melakukan tindakan.

Refrensi [13] melaporkan bahwa hanya $57 \%$ yang merasa pengetahuan farmakologi barasal dari pendidikan. Sementara laporan studi yang dilakukan oleh Refrensi [20] mengungkapkan bahwa sekolah keperawatan mengalami kelemahan dalam memberikan praktik farmakologi sehingga para lulusan memiliki keterbatasan dalam memberikan terapi atau pengobatan. Perawat diharapkan dapat memberikan perawatan sekaligus pendidikan pada pasien melalui 
pengetahuan dan keterampilan yang dimiliki.

Pertimbangan faktor resiko dan komplikasi yang dapat terjadi pada pasien DM yang menjalani terapi insulin, maka dibutuhkan kriteria khusus perawat yang dapat berkontribusi mengatasi masalah tersebut, seperti perawat Registered Nurse (RN) dengan spesifikasi spesialis klinis/clinical nurse specialists (CNSs) [21]. Perawat praktisi yang memiliki kewenagan dan kapasitas pada praktik klinik dalam memulai, mengelola, merubah bahkan menyesuaikan terapi pasien DM tanpa otoritas dokter [22].

\section{Penelitian Refrensi}

mengungkapkan bahwa, pengelolaan terapi yang dilakukan oleh seorang perawat spesialis deiabetes terbukti memiliki efek positif secara seignifikan mengurangi jumlah kesalahan dan mengurangi lama rawat pasien DM di RS dengan ( $p=0,016)$.

Studi ini melihat bahwa pendidikan tidak menjadi bagian penting dalam merubah perilaku, tapi sejauh mana paparan informasi dan ketersediaan informasi yang terus diterima seperti melalui pendidikan dan pelatihan pengelolaan terapi insulin atau manajemen DM, baik dari pendidikan formal maupun non formal sehingga mampu mempengaruhi perilaku perawat dalam mengelola terapi insulin pada pasien dengan DM.

Hubungan Pengetahuan dengan perilaku perawat dalam pemberian terapi insulin non critical
Hasil analisis bivariat diperoleh bahwa dari uji Chi-Square diperoleh $p$ value $=0,386$ menunjukkan bahwa tidak ada hubungan yang signifikan antara pengetahuan responden dengan perilaku perawat dalam pemberian terapi insulin dalam situasi non critical pada pasien DM di BLUD RS Benyamin Guluh.

Sebuah penelitian lain melaporkan bahwa kesalahan biasa terjadi dalam menangani insulin diantaranya karena salah mengidentifikasi, kurangnya komunikasi antar tim kesehatan lainnya, kurangnya pengetahuan manajemen diabetes, kesalahan interpreatsi nama insulin yang mirip, dan kegagalan dalam koordinasi administrasi insulin. Kesalahan yang terjadi dalam pemberian terapi insulin akibat kurangnya pengetahuan dikhawatirkan bisa membahayakan pasien, mengingat terapi insulin sangat beresiko bila tidak diketahui secara konsep tentang fungsi dan cara kerjanya.

Tantangan terbesar bagi perawat adalah mempertahankan eksistensi pengetahuan, keahlian dan kualitas dalam memberikan pelayanan keperawatan secara positif agar memberikan efek terhadap perawatan pasien di RS [24].

Pengetahuan perawat dalam menangani terapi insulin pada pasien DM, seperti variabel pendidikan dan pelatihan sebagai variabel confounding yang mungkin dapat mempengaruhinya. Minimnya materi 
mengenai farmakologi tentang high alert khususnya konsep insulin di pendidikan serta pelatihan pengelolaan terapi insulin yang masih kurang juga program CPD di RS yang belum berjalan dengan baik

Hubungan Sikap terhadap perilaku perawat dalam pemberian terapi insulin non critical

Hasil uji Chi-Square diperoleh $p$ value $=0,276$ yang menunjukkan bahwa tidak ada hubungan yang signifikan antara sikap sikap negatif dengan positif dengan perilaku pemberian terapi insulin dalam situasi non critical pada pasien DM di BLUD RS Benyamin Guluh. Hasil analisis ini diyakini karena frekuensi jumlah sikap positif dan negatif responden tidak terpaut jauh antara sikap positif dan negatif. Refrensi [25] dalam teorinya mengemukakan bahwa sikap positif/negatif seseorang tergantung respon terhadap objek atau lingkungan dimana mereka berada. Hal ini tergantung pada stimulus yang diterima bersifat positif atau negatif yang lebih dominan.

Stimulus positif yang lebih kuat terbukti mampu merubah perilaku. Studi di Jepang melaporkan bahwa program CPD dapat berjalan walau terdapat berbagai hambatan dari organisasi dan pimpinan mereka. Berdasarkan hasil analisis diketahui bahwa sikap rekan kerja yang konsisten saling dengan mendukung dalam mengikuti perkembangan ilmu dan tekhnologi kesehatan sebagai pemicunya.
Hasil penelitian ini menyimpulkan bahwa sikap responden menjadi positif atau neggatif tergantung seberapa kuatstimulus yang diterimanya. Kecenderungan sikap positif dan negatif yang memiliki persentase hampir sama mempengaruhi diyakini mempengaruhi nilai signifikan perilaku perawat dalam pemberian terapi insulin.

\section{KESIMPULAN}

Responden dalam penelitian ini didominasi oleh perempuan yang merupakan pegawai BLUD RS Benyamin Guluh Kabupaten Kolaka Provinsi Sulawesi Tenggara yang masih aktif dan bekerja di ruang bedah dan penyakit dalam. Berdasarkan analisis bivariat melalui uji ChiSquare diperoleh tidak ada perbedaan bermakna pada pengetahuan, sikap pada perilaku pemberian insulin. Responden sebagian besar merupakan lulusan D III keperawataan (AKPER)/Pendidikan Vokasi.

\section{DAFTAR PUSTAKA}

1. Beneby, N., Isaacs, C., King, L., Taylor, A., Thompson, C., \& Ward, J. (2015). Knowledge, Attitudes and Perceptions of Patients towards Insulin Therapy at Primary Care Centers in Trinidad. 2-7.

2. Chang, E.., Daly, J., Elliiot, D. (2010). Patologi : Aplikasi pada praktik 
eperawatan. Jakarta : EGC.

3. Guariguata, L., Whiting, D. R., Hambleton, I., Beagley, J., Linnenkamp, U., \& Shaw, J. E. (2014). Global estimates of diabetes prevalence for 2013 and projections for 2035. Diabetes Research and Clinical Practice, 103, 137-149.

4. Riset Kesehatan Dasar (2013). RISKESDAS 2013. Retrieved from http://www.litbang.depkes.go.id

5. Vyas, P., Bhattarai, R., \& Acharya, B. (2017). Knowledge, attitude and practice of type 2 diabetic patients of selected outreach clinic, Dharan, Nepal, 0.

6. Diggle, J. (2015). The management of diabetes and best practice in injection technique. Nurse Prescribing, 13, 72-78 $7 p$.

7. Desouza, C. V., Bolli, G. B., \& Fonseca, V. (2010). Hypoglycemia, diabetes, and cardiovascular events. Diabetes Care, 33, 1389-1394

8. Al-Sarayra, L., Khalidi, R.S. (2012).

9. Awareness and knowledge about diabetes mellitus among students at AlBalqa' Applied University. Pak. J. Nutr. 11, 1023-1028.

10. Bilous, R. \& Donelly, R. (2014). Buku pegangan diabetes edisi ke 4. Jakarta: Bumi Medika

11. Kasprzak, C., \& Certina, H. (2016). Insulin:The patient noticed his insulin box was different than [what] he had before.
He should have received Novolin $B$ ge $\mathrm{NPH}$ and had been given Novolin® ge $30 / 70$ in error. HOSPITAL NEWS, (December 2015), 17.

12. Blanco, M., Hernandez, M. T., Strauss, K. W.,\& Amaya, M. (3013). Prevalence and risk factors of lipohypertrophy in insulininjecting patiens with diabetes. Diabetes and metabolism, 39(5), 445-453

13. Kelly, J. L. (2014). Continuous Insulin Infusion: When, Where, and How? Pharmacy and Therapeutics Continuous, 27(Iv), 218-222. Retrieved from https://www.idf.org/sites/default/files/attac hments/article_263_en.pdf

14. Derr, Sivanandy, Bronich-Hall, L., \& Rodriguez, A. (2007). Insulin-related knowledge among health care professionals in internal medicine. Diabetes Spectrum, 20(3), 177-185 9p. Retrieved from http://search.ebscohost.com

15. Polit, D. F., \& Beck, P. \&. (2012). Essential of nursing research: Methods, and apprasial and utilization. Philadelphia: Liponcott williams \& Walkins

16. Prompahakul, C., Nilmanat, K. \& kongsuwan, N. (2011). Nurses' caring behavioursfor dying patients in southern Thailand. NurseMedia Journal of Nursing, Vol 1,2, Juli 2011, P. 147-158. Pince of Songkla University, Thailand

17. Sopiah. Syihabudhin . (2011). Perilaku 
Organisasi. Yogyakarta: Andi

18. Sullivan, M. M., O’Brien, C. R., Gitelman, S. E., Shapiro, S. E., \& Rushakoff, R. J. (2010). Impact of an Interactive Online Nursing Educational Module on Insulin Errors in Hospitalized Pediatric Patients. Diabetes Care, 33(8), 1744-1746.

19. Shahrokhi, A., Ebrahimpour, F., \& Ghodousi, A. (2013). Factors effective on medication errors: A nursing view. Journal of Research in Pharmacy Practice, 2(1), 18-23.

20. Robbin, S.P \& Judge, T.A. (2015). Organizational behavior. Fifteenth Edition. New Jersey: Pearson

21. Dilles, T., Vander Stichele, R. R., Van Bortel, L., \& Elseviers, M. M. (2011). Nursing students' pharmacological knowledge and calculation skills. Ready for practice? Nurse Education Today, 31(5), 499-505.

22. Levich, B. R. (2011). Diabetes management: optimizing roles for nurses in insulin initiation. Journal of Multidisciplinary Healthcare, 4, 15-24

23. Richardson, G. C., Derouin, A. L., Vorderstrasse, A. A., Hipkens, J., \& Thompson, J. A. (2014). Nurse Practitioner Management of Type 2 Diabetes. The Permanente Journal, 18(2), e134-e140.

24. Carey,Nicola. (2008). An Evaluation of a Diabetes Specialist Nurse Prescriber on the System of Delivering Medicines to
Patients with Diabetes.Diabetes care.2(1)24-31.

25. Cleary M, Horsfall J, Hara-aarons $M O$, Jackson D, Hunt GE. (2011). The views of mental health nurses on continuing professional.

26. Gibson. (2010). Organisasi:

Perilakustruktur proses.Jakarta: Erlangga 